Journal homepage: http://www.interscience.org.uk

DOI: $10.18535 /$ ijahm/v7i4.10

Impact factor: 4.415

\title{
Comparative Pharmaceutical Study of White \& Black Gunja (Abrus prectorius L.) Kernels
}

\author{
Dr. Dev Nath Singh Gautam \\ Associate Professor, Department of Rasa Shastra, Faculty of Ayurveda, IMS, BHU, Varanasi
}

\begin{abstract}
A.precatorius (Gunja) is belonging to family fabaceae was usually known as crabs' eye, Indian liquorice. It is a woody twining found almost in all parts of India, ascending to an altitude of $3500 \mathrm{ft}$. In the classical texts of Rasa Shastra, A. precatorius is mentioned under Upavisha Gana (semi-poisonous). Several methods of purifications were mentioned in the classical text of Ayurveda. After proper purification, Gunja has been used as a treatment for various diseases like alopecia, itching, edema, urinary disorders, etc. Three seed varieties of Gunja and their different Shodhana methods were mentioned in the ancient classical literature. But there is no any clue who described that which method is superior to the other and in what respect. Therefore the current study was carried out to evaluate the comparative effect of Shodhana of white and black kernels of A. prectorius through Godugdha (cow's milk) and Kanji (sour gruel) by using phytochemical study. White and black varieties of kernels of A. prectorius were subjected to Swedana process (Shodhana) in cow milk and Kanji (sour gruel) separately for six and three hours respectively. After purification both samples were found decreased in weight, change in color and decrease the number of phytoconstituents was observed. In Ashodhit kernels of white Gunja (Wk), 3 spots, Shodhana with cow's milk 4 spots and Kanji Shodhita Gunja 7 spots were observed at different Rf values. While in Ashodhita kernels of black Gunja (Bk), 7 spots, Shodhana with milk 5 spots and Kanji Shodhita Gunja 6 spots were observed at different Rf values. White varieties of Gunja seed was found more prominent as compared with black seed.
\end{abstract}

KEYWORDS: A. prectorius, Gunja, Shodhana, Upavisha

\section{INTRODUCTION}

Ayurveda is the most popular prehistoric traditional system of medicine about 5000 years BC, practiced in India and other nation state (Sharma et al., 2016). According to Ayurveda, it is believed that after proper Shodhana (purification) any metal, mineral or plant drug which contains Visha (poison) can change into Amrita (nectar) (Manisha, 2016). In the classical texts of Rasa Shastra, A. precatorius belongs to Upavishagana (semi-poisonous) (Sharma, 1998). Abrus precatorius Linn., (Fabaceae) usually known as crabs' eye, Indian liquorice is a woody twining found almost in all parts of India, ascending to an altitude of $3500 \mathrm{ft}$. Leaves of the plant are characterized by pinnate and glabrous oblong, obtuse, truncate at both ends, apprised hairy, with many leaflets arranged in pairs. Stems are cylindrical, wrinkled, bark smooth-textured, brown. Flowers are pink or pinkish-white numerous, auxiliary racemes. Calyx is long and hispid with 9-12 $\mathrm{mm}$ long petals. Stamens are monadelphous, subsessile ovary and many ovules, with style incurved. Pods are oblong, a little inflated, fulvo-puberulent. Glossy seed, bright scarlet, with the area around the hilum (point of attachment) being black (Kritikar and Basu, 1999). Three varieties of A. precatorious (black, white and red) commonly found throughout the tropics. A. precatorious seeds enclose with toxic chemical 
constituent like abrin, abrussic acid, choline, urease, hypaphorine and much more alkaloids and steroidal oils (Gautam et al., 1998). The fatal dose of abrin is found to be $0.1-1 \mu \mathrm{g} / \mathrm{kg}$ in adults (Dickers et al., 2003). In classical texts of Ayurveda, several methods of purifications for A. precatorious were mentioned. After being processed through purification, seeds, roots and leaves of A. precatorious have been used to treat alopecia, itching, edema, urinary disorders, etc. Three seed varieties of Gunja and their different Shodhana methods were mentioned in the Ayurvedic classical literature. However there is no any evidence who described that which method is superior to the other and in what respect. The present study was carried out to evaluate the comparative effect of Shodhana of white and black kernels of A. prectorius through cow's milk and Kanji (sour gruel) by using phytochemical study.

\section{MATERIAL AND METHODS}

\section{Shodhana in cow's milk and Kanji}

The Shodhana process was performed of both (white and black) seed kernels (250 gm each) of A.precatorious by Swedana method (Dola-Yantra) in cow's milk and Kanji for 6 and 3h respectively. After that, the shodhita kernels of both varieties were washed with warm water and kept for drying in the shade. (API, 2008)

\section{Table 1: Ingredients of Kanji}

\begin{tabular}{lll}
\hline Drug & $\begin{array}{l}\text { Part } \\
\text { used }\end{array}$ & Quantity \\
\hline Oryze sativa L. & Seeds & $5 \mathrm{~kg}$. \\
Dolichos uniflorus Lamk & Seeds & $5 \mathrm{~kg}$. \\
Sodium Chloride & & $5 \mathrm{~kg}$. \\
Vigna radiate $\mathrm{L}$. & Dough & $1.25 \mathrm{~kg}$ \\
Curcuma longa L. & Rhizome & $1.25 \mathrm{~kg}$ \\
Brassica nigra L. & Seed & $1.25 \mathrm{~kg}$ \\
Ferula assafoetida L. & Resin & $1.25 \mathrm{~kg}$ \\
Mustard & Seed Oil & $1.25 \mathrm{~mL}$. \\
Bambusa arundinaceae Retz. & Leaves & $1.25 \mathrm{~kg}$ \\
Cuminum cyminum L. & Seeds & $650 \mathrm{gm}$. \\
Zingiber officinale Rosc. & Rhizome & $650 \mathrm{gm}$. \\
Oryze sativa L. & & $160 \mathrm{Lt}$. \\
\hline
\end{tabular}

\section{Preparation of Kanji (Sour gruel)}

Rice (O. sativa) and Kulthi (D. biflorus) were taken in stainless steel pots. 40 liters of distilled water were added separately. The pots were placed over a gentle heat, boiled and reduced to one-fourth and filtered through cotton cloth. Both the prepared Kwath (decoction) of rice and Kulthi were mixed and kept in an earthen pot layered inside with mustard oil. The Hingu ( $F$. assafoetida) was roasted in oil, and all other ingredients (3-8) were also kept in the pot. The mouth of the pot was tied by cloth and kept for 15 days and filtered before use. Thus 20 liters of Kanji was prepared (Anonymus, 2001).

Estimation of different physicochemical values

Extraction with polar solvents (ethanol) was made with the help of soxhlet apparatus, and the percentage of the extract was calculated after evaporating the alcoholic solvents. For Thin layer chromatography (TLC) analysis both varieties of Gunja were analyzed on pre-coated aluminum silica gel plates (60 F-254) as the stationary phase. The varying polarity of different mixtures of solvents (Mobile phases, Toluene: Ethyl formate: Formic acid: Water (50:40:10:1) was used for developing the chromatogram. Spraying of different 
Dr. Dev Nath Singh Gautam , International Journal of Ayurvedic \& Herbal Medicine 7(4) July.-Aug.2017 (2700-2705)

reagents confirmed the presence of various phytochemical and their respective $\mathrm{Rf}$ values were calculated and recorded (Sharma, 2015).

\section{Estimation of heavy metals in Kernels of Gunja}

2 gm of kernel powder of both varieties of Gunja were taken in $100 \mathrm{~mL}$ of the beaker. $25 \mathrm{~mL}$ of conc. nitric acid was measured accurately and added it in kernel powder. The beaker was covered with a watch glass and heated on a hot plate until all kernel powder was dissolved. After that, the beaker was kept out for cooling for 5 minutes and then added one $\mathrm{mL}$ aliquots of $10 \mathrm{~mL}$ of hydrogen peroxide. The mixture was heating continue until the volume was reduced up to $5 \mathrm{~mL}$. After cooling for 5 minutes, all the mixture was transferred to $100 \mathrm{~mL}$ volumetric flask and makeup to the mark with distilled water and filtered it with the help of filter paper to remove the organic plastic precipitate (Anonymous, 2001).

\section{Results:}

\section{Details of Ashodhita (crude) samples}

Weight of white and black kernels of A. precatorious-250gms

Table 2: Details of Shodhita samples of white kernel of Gunja

\begin{tabular}{|c|c|c|}
\hline Parameters & Milk & Kanji \\
\hline Consumed volume of vehicle & 3.5 liters & 4 liters. \\
\hline Time consumed in the entire process of Shodhana & $7 \mathrm{hrs}$ & $4.2 \mathrm{hrs}$. \\
\hline $\begin{array}{l}\text { Net volume of the total cow's milk and Kanji remained } \\
\text { in the vessel of Dola-Yantra after the Shodhana process } \\
\text { was over }\end{array}$ & 1.5 liters (semisolid) & 1.6 liters (semisolid) \\
\hline $\begin{array}{l}\text { The weight of white and black kernels of Gunja obtained } \\
\text { after the Shodhana process and dried in the shade. }\end{array}$ & 220 gm. & $225 \mathrm{gm}$. \\
\hline Color of Vehicle & $\begin{array}{l}\text { Color of the milk } \\
\text { changes from the } \\
\text { milky to light brown to } \\
\text { dark brown color }\end{array}$ & $\begin{array}{l}\text { Color of the Kanji } \\
\text { changes from the bright } \\
\text { yellow to dark yellow } \\
\text { color }\end{array}$ \\
\hline Color of Kernel & $\begin{array}{l}\text { The color of white } \\
\text { kernels changed light } \\
\text { cream to brown. }\end{array}$ & $\begin{array}{l}\text { The color of white } \\
\text { kernels changed light } \\
\text { cream to yellow color. }\end{array}$ \\
\hline
\end{tabular}

Table 3: Details of Shodhita samples with B lack kernel of Gunja

\begin{tabular}{|c|c|c|}
\hline Parameters & Milk & Kanji \\
\hline Volume of cow's milk consumed & 3 liters & 3 liters. \\
\hline $\begin{array}{l}\text { Time consumed in the entire process of } \\
\text { Shodhana }\end{array}$ & $6.8 \mathrm{hrs}$ & $6 \mathrm{hrs}$. \\
\hline $\begin{array}{l}\text { Net volume of the total cow's milk } \\
\text { remained in the vessel of Dola-Yantra } \\
\text { after the Shodhana process was over }\end{array}$ & 1.5 liters (semisolid) & 1.7 liters (semisolid) \\
\hline $\begin{array}{l}\text { The weight of white and black kernels of } \\
\text { Gunja obtained after the Shodhana } \\
\text { process and dried in the shade. }\end{array}$ & $215 \mathrm{gm}$. & $225 \mathrm{gm}$. \\
\hline Color of vehicle & $\begin{array}{l}\text { Color of the milk changes } \\
\text { from the milky to light } \\
\text { brown to dark brown color }\end{array}$ & $\begin{array}{l}\text { Color of the Kanji changes from } \\
\text { the bright yellow to dark yellow } \\
\text { color }\end{array}$ \\
\hline Color of Kernel & $\begin{array}{l}\text { The color of black kernels } \\
\text { changed black to dark black. }\end{array}$ & $\begin{array}{l}\text { The color of black kernels } \\
\text { changed black to dark chocolaty. }\end{array}$ \\
\hline
\end{tabular}


Dr. Dev Nath Singh Gautam , International Journal of Ayurvedic \& Herbal Medicine 7(4) July.-Aug.2017 (2700-2705)

Table 4: Estimation of heavy metals in white kernel of Gunja

\begin{tabular}{|c|c|c|c|c|}
\hline Element & Wavelength & Instrument detection limit & Concentration in ppm & Limit \\
\hline Cadmium & 228.802 & 0.0029 & Not detected & $0.3 \mathrm{ppm}$ \\
\hline Lead & 220.353 & 0.0450 & Not detected & $10 \mathrm{ppm}$ \\
\hline Mercury & 253.652 & 0.0580 & Not detected & $1 \mathrm{ppm}$ \\
\hline Arsenic & 193.696 & 0.0530 & Not detected & $3 \mathrm{ppm}$ \\
\hline
\end{tabular}

Table 5: Estimation of heavy metals in black kernel of Gunja

\begin{tabular}{|c|c|c|c|c|}
\hline Element & Wavelength & Instrument detection limit & Concentration in ppm & Limit \\
\hline Cadmium & 228.802 & 0.0029 & Not detected & $0.3 \mathrm{ppm}$ \\
\hline Lead & 220.353 & 0.0450 & Not detected & $10 \mathrm{ppm}$ \\
\hline Mercury & 253.652 & 0.0580 & Not detected & $1 \mathrm{ppm}$ \\
\hline Arsenic & 193.696 & 0.0530 & Not detected & $3 \mathrm{ppm}$ \\
\hline
\end{tabular}

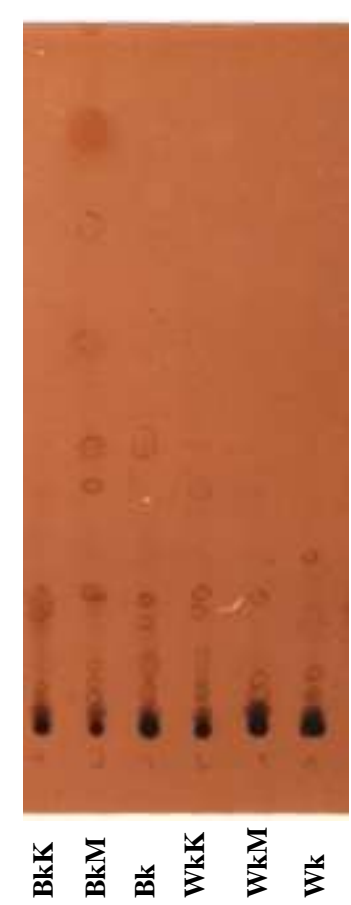

Fig. No 1: TLC profile of alcohol extractive

Solvent system, Toluene: Ethyl formate: Formic Acid: Water

$50 \quad 40 \quad 10 \quad 1$

Table 6: Rf values of alcohol extractive (from TLC plate) of white Gunja kemels in solvent system Toluene: Ethyl formate: Formic acid: Water (50:40:10:1)

\begin{tabular}{|c|c|c|c|}
\hline Rf values & \multicolumn{3}{|c|}{ Ashodhita and Shodhita kernels of Gunja } \\
\hline & Wk & WkM & WkK \\
\hline 0.014 & + & + & + \\
\hline 0.037 & + & + & + \\
\hline 0.066 & + & + & + \\
\hline 0.089 & - & - & + \\
\hline 0.171 & - & - & + \\
\hline 0.193 & - & + & + \\
\hline 0.334 & - & - & + \\
\hline
\end{tabular}

Spraying reagent- Anisaldehydesulphuric aci

Abbreviations: Wk- White Gunja kernels, WkM-White Gunja kernels Shodhita in cow's milk, WkK- White Gunja kernels Shodhita in Kanji. 
Dr. Dev Nath Singh Gautam , International Journal of Ayurvedic \& Herbal Medicine 7(4) July.-Aug.2017 (2700-2705)

Table 7: Rf values of alcohol extractive (from TLC plate) of black Gunja kemels in solvent system Toluene: Ethyl formate: Formic acid: Water (50:40:10:1)

\begin{tabular}{|c|c|c|c|}
\hline Rf values & \multicolumn{3}{|c|}{ Ashodhita and Shodhita kernels of Gunja } \\
\hline & Bk & BkM & BkK \\
\hline 0.014 & + & + & + \\
\hline 0.037 & + & + & + \\
\hline 0.066 & + & + & + \\
\hline 0.133 & + & - & - \\
\hline 0.193 & + & - & - \\
\hline 0.207 & + & + & + \\
\hline 0.358 & - & + & + \\
\hline 0.408 & + & - & - \\
\hline 0.550 & - & - & + \\
\hline
\end{tabular}

Spraying reagent- Anisaldehydesulphuric acid

Abbreviations: Bk- black Gunja kernels, BkM-black Gunja kernels Shodhita in cow's milk, BkK- black Gunja kernels Shodhita in Kanji.

\section{Discussion:}

At present era, the importance of the standardization technique increased due to the therapeutic potential of the medicinal plant. The recent standardization techniques accessible make the detection and evaluation of plant drugs more trustworthy, precise and reasonably priced (Kunle et al., 2012). Traditional medicinal plants have played a major role in the healthcare system of medicine. In the present study, I have standardized the effect of Shodhana on two varieties of the seed (kernels) of A. precatorious both studies physicochemical and phytochemical. The white and black varieties of the seed of $A$. precatorious are proven to be of potent and high-quality medicinal value by different tribal of the states of India (Gautam, 2017). Therefore there is a need to precisely build up a standard monograph for the plant which will provide an excellent source of information to the customers, researchers as well as manufacturers. In this context, two varieties (white and black) of Gunja were processed in cow's milk and Kanji and subjected to various physicochemical and phytochemical studies. The observations regarding organoleptic character showed that there was a change in the color of both varieties of Gunja i.e. white and black. In WkM, the color of white kernels changed light cream to brown while $\mathrm{BkM}$, the color of black kernels changed light cream to yellow color. The Same color change was observed in both samples when treated with Kanji. In WkK, the color of white kernels changed light cream to yellow color whereas, in BkK, the color of black kernels changed black to dark chocolaty. Both varieties of Gunja were found soft in nature after complete Shodhana process (Table 2, 3). Extractive values are giving useful information about active phytoconstituents which is already present in different part of plants using different solvents (Sasidharan et al., 2011). In medicinal plants, a number of metal and minerals are present. These metal and mineral were important for build up nutrition in the human body. Moreover, many other elements (cadmium, lead, mercury, arsenic) are also present in plants which are caused a harmful effect in the human body (Baker and Brooks, 1989; Lasisi et al., 2005). The presence of these elements in the soil involves their accumulation in medicinal plants (Khan et al., 2007). The ethanolic extract of both varieties of Gunja was performed for detection of heavy metal analysis with the help of Atomic absorption spectroscopy (AAS). The elements analyzed were cadmium, lead, mercury and arsenic and their amounts were recorded in parts per million (ppm). The results (Table 4, 5) show that after Shodhana, all the elements were not detected in our permicible limits. The aim of the present research work is to carry out the effect of Shodhana on the different seed variety of Gunja. In our Ayurvedic classical text different Shodhana process is mentioned for the same drug. For that reason, in a current 
scenario, many questions were raised like which of the Shodhana process is more effective or which variety of plant drugs is more potent, etc. (Gautam, 2016). In this context, two varieties of Gunja (white and black) were processed with two different vehicles with same Shodhana process. After purification process, both varieties of Gunja were subjected to extraction with ethanol. Both ethanolic extracts were performed for TLC (thin layer chromatography) in solvent system Toluene: Ethyl formate: Formic acid: Water (50:40:10:1) (figure 1). The retardation factor (Rf) value was calculated and recorded. In Ashodhit kernels of white Gunja, three spots at Rf values $(0.014,0.037,0.066)$ were present. After Shodhana with milk 4 spots at $\mathrm{Rf}$ values $(0.014,0.037,0.066,0.193)$ were observed but in Kanji Shodhita Gunja 7 spots were observed at Rf values $(0.014,0.037,0.066,0.089,0.171,0.193,0.334)$ (Table 6). In Ashodhit kernels of black Gunja, 7 spots at Rf values $(0.014,0.037,0.066,0.133,0.193,0.207,0.408)$ were present. After Shodhana with milk 5 spots at Rf values $(0.014,0.037,0.066,0.207,0.408)$ were observed but in Kanji Shodhita Gunja 6 spots were observed at $\mathrm{Rf}$ values $(0.014,0.037,0.066,0.207,0.358,0.550)$ (Table 7). The variations of $\mathrm{Rf}$ value may be explained due to Shodhana. During Shodhana process, some constituents were either soluble in milk or Kanji. It might be due to the fact that extended contact of the kernel with milk and Kanji not only reduce the phytoconstituents but also converts the highly toxic phytoconstituents into less toxic (Gautam, 2016). Another hypothesis can be drawn that during Shodhana some highly toxic phytoconstituents were leached out and some therapeutically active phytoconstituents were absorbed with vehicle (either milk, Kanji). Which has been increased the therapeutic value of seeds?

\section{Conclusion:}

It was found that the phytochemicals decreased in Shodhita samples of black Gunja while increased in Shodhita sample of white Gunja due to leaching and absorption. Some compounds were absent in Shodhit samples of black Gunja while some new compounds were present in Kanji Shodhit sample of white Gunja. The study showed that white varieties and Shodhana in Kanji is more effective. Therefore, all the analytical tools used in this study can be used as a marker for Shodhana for the both samples.

\section{REFERENCES}

1. Sharma V, Reddy KRC, Gautam DNS. An ayurvedic review on therapeutic potentials of manahshila: a literature review. Innov Journal of Ayruvedic Science, 2016; 4(3);1-6.

2. Manisha D. Poisonous plants as medicine after Shodhana: A review. Unique Journal of Ayurvedic Herbal Med, 2016; 4(2), 1-4.

3. Sharma S. Rasatarangini (Rewrite by Shastri K.), $11^{\text {th }}$ Edition, Varanasi, Motilal Banarasidas, Publisher, 1998, Verse 2/37.

4. Kritikar KR, Basu BD. Vol. 1. Dehra Dun: International Book Distributors; 1999. Indian Medicinal Plants; 1999, p. 766.

5. Gautam DNS, Banerji R, Mahrotra S. Effect of Shodhana on the toxicity of abrus precatorius. Ancient Science of Life, 1998; 18(2), 127-129.

6. Dickers KJ, Bradberry SM, Rice P, Griffiths GD, Vale JA. Abrin poisoning. Toxicol Reviews, 2003; 22(3), 137-142.

7. Ayurvedic Pharmacopoeia of India (API). First edition. Part-II, Vol-II, Appendices-2. New Delhi; Government of India, Ministry of Health and Family Welfare, Department of AYUSH, 2008; 159161.

8. Anonymus. The Ayurvedic Formulary of India. $2^{\text {nd }}$ ed. New Delhi: Ministry of Health and Family Welfare, Department of AYUSH Government of India Publication, 2001; p. 8.

9. Sharma V, Hem, Seth A, Maurya SK. Standardization and antioxidant activity of an Ayurvedic formulation Kushavleha. International Journal of Green Pharmacy, 2015; 9(4), 55-62. 
10. Anonymous, The Ayurvedic Pharmacopoeia of India. Reprinted $1^{\text {st }}$ ed, Govt. of India: Ministry of Health and Family Welfare; Part I, Vol. I, Appendix 2, (2.3.3), 2001; p 150.

11. Kunle O, Folashade, Egharevba H, Ahmadu O, Ochogu P. Standardization of herbal medicines - A review. International Journal of Biodiversity Conservation, 2012; 4(3), 101-112.

12. Gautam DNS. Comparative Study of Ashodhit And Shodhit Gunja (Abrus Precatorius) Pericarps. International Journal of Research in Ayurveda and Pharmacy. 2017; 8 (Suppl 2), 142-145.

13. Sasidharan S, Chen Y, Saravanan D, Sundram KM, Yoga L. Extraction, Isolation and Characterization of Bioactive Compounds from Plants' Extracts. African Journal of Traditional and Complementary Alternatice Medicine, 2011;8(1), 1-10.

14. Baker AJ, Brooks RR. Terrestrial higher plants which hyperaumulete metallic elements: A review. Biorecovery, 1989;1(2): 81-126.

15. Lasisi AA, Yusuff AA, Ejelonu BC, Nwosu EO, Olayiwola MA. Heavy metals and macro-nutrients content in selected herbal plants of Nigeria. Internatinal Journal of Chemistry, 2005; 15:147-54.

16. M.A. Khan, I. Ahmad, I. Rahman. (2007), Effect of environmental pollution on heavy metals content of Withania somnifera. Journal of Chinese Chemical Society. 54:339-43.

17. Gautam DNS. Shodhana sanskara of Red Gunja (Abrus precatorius L.) Kernels: A Pharmaceutical Study. International Journal of Ayurvedic Medicine, 2016; 7(3),157-159. 